\title{
肺癌の外科療法
}

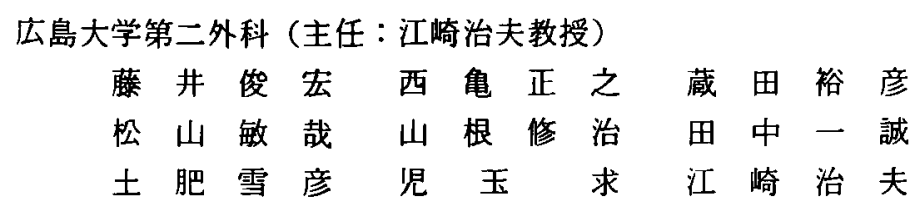

\section{OPERATIVE EVALUATION OF LUNG CANCER}

Toshihiro FUJII, Masayuki NISHIKI, Yuhiko KURATA, Toshiya MATSUYAMA Syuji YAMANE, Issei TANAKA, Kiyohiko DOHI, Motomu KODAMA and Haruo EZAKI

The 2nd Department of Surgery, Hiroshima University School of Medicine, Hiroshima

1966年より1977年までの間の当科に於ける原発性肺澏症例は 121 例で，開胸率80\%（97 例), 切除率71\% (86例) であった.

全肺癌術後 5 年実測生存率は.33\%であった. surgical TNM 分類での予後は，I 期 $59 \%$,

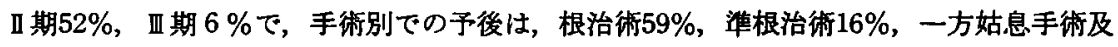
び試験開胸率には 5 年生存はなかった。

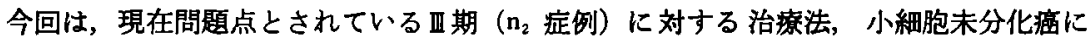
対する手術適応, 高齢者肺演と全摘術, 及び早期死亡例等の顊点から考察を行い, 手術適 応及び手術法を厳しく設定し，細心の管理の下に手術療法を施行すれば街後成績は大いに 期待できるものと考えられる。

はしめに

昭和47年の日本に於ける肺癌の死亡数が，肺結核の死 亡数を上まわって以来, 欧米諸国と同様の傾向を示して いる. 又, 近年全癌に於ける肺癌の占める割合が激增し ている。

しかし，肺癌の外科的療法が確立しつつあるとはい え，なお，他の澏の予後に比し良いとはいえない，我々 の教室が，昭和27年に肺癌に対する手術療法を施行して 以来, 25年を経過し, 今回比較的 follow-up の出来てお $\eta$ ，又皘極的に肺癌の外科的療法に取り組み始めた昭和 41年より昭和52年12月末迄の約 11 年間に経験した肺癌手 術症例 (97例) について検討した.

\section{I 当教室に於ける手術成緹}

1) 開胸率と切除率

原発性肺癌症例は，121例で開胸率80\%(97例)，切除 率71\%（86例）であった. いすれれも他の施設より高率で あるが，その理由の 1 つしては当院内科からの稆介
が，かなりの比率を占め，内科及び外科で手術適応を検 討した上での症例であるためと考えられる。

\section{2）肺癌の発症症状及び診断動機}

表 1 の如く，肺病変95例 $(79 \%)$ と最も多いが，初診 時の主訴は, 咳嘈, 喀痰, 血痰の 3 大呼吸器症状が, 半 数近くを占めている. 又, 脱転移症状, 頸部隀瘤を主訴 として来院する場合もある.一方, 検診により初めて胸

表 1 肺症発症症状及び診断動機

\begin{tabular}{|c|c|c|}
\hline & 例 数 & $\%$ \\
\hline 脳 転 移 & 10 & 8 \\
\hline 頊 部 腫 雷 & 6 & 5 \\
\hline 肺病変 (娭䥻) & $95(39)$ & $79(32)$ \\
\hline 倦 袁 感 & 5 & 4 \\
\hline 発 & 3 & 2 \\
\hline 痛 & 2 & 2 \\
\hline 計 & 121 & 100 \\
\hline
\end{tabular}




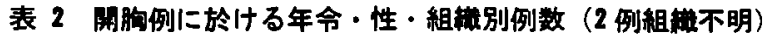

\begin{tabular}{|c|c|c|c|c|c|c|c|c|c|}
\hline \multirow{2}{*}{ 年 龄 } & \multicolumn{4}{|c|}{ 男 } & \multicolumn{4}{|c|}{ 女 } & \multirow[b]{2}{*}{ 部 } \\
\hline & $\mathrm{Sq}$ & Ad & $\begin{array}{l}\text { large } \\
\text { cell }\end{array}$ & $\begin{array}{l}\text { small } \\
\text { cell }\end{array}$ & Sq & Ad & $\begin{array}{l}\text { large } \\
\text { cell }\end{array}$ & $\begin{array}{l}\text { small } \\
\text { cell }\end{array}$ & \\
\hline $35-39$ & & 1 & & & & 1 & & & 2 \\
\hline $40 \sim 44$ & 1 & 1 & & 1 & & 1 & & & 4 \\
\hline $45-49$ & 3 & 1 & 1 & 1 & 1 & 1 & & & 8 \\
\hline $50 \sim 54$ & 6 & 7 & & 1 & & & & & 14 \\
\hline $55 \sim 59$ & 9 & 3 & 2 & & 3 & 9 & & & 26 \\
\hline $60 \sim 64$ & 12 & 2 & & & & 3 & 1 & & 18 \\
\hline $65-69$ & 9 & 1 & 1 & & 1 & 1 & & & 13 \\
\hline $70 \sim 74$ & 4 & 2 & & & 1 & 1 & & & 8 \\
\hline $75 \sim 79$ & & 2 & & & & & & & 2 \\
\hline 壾 & 44 & 20 & 4 & 3 & 6 & 17 & & & 95 \\
\hline
\end{tabular}

部の異常陰影を指摘され来院する場合が 3 割近くを占め ており，検診間隔に問題はあるが，スクリーニングと早 期発見に於ける意義は媣い。

\section{3）開胸率に於ける性別，年战命}

開胸及び切除症例の平均年龄は，腺癌，扁平上皮癌共 に59歳で, 最高㱓者は76歳，最若年者は37歳であった. 男女比は表 2 の如く，男性は 女性に 比し 約 3 倍多い。 又, 扁平上皮癌に於いては，男性は女性に比し約 7 倍多 く，女性では，他の報告と同様腺滰の比率が高い，年齢

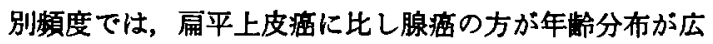
いよらである。

4) 全肺病術後実湘生存率

图 1 の如く，肺癌術後全症例での 5 年実測生存率は33 \%であった. 55歳末満及び65歳以上の高跉者では20\%未

\section{图 1 肺庹術後実測生存案}

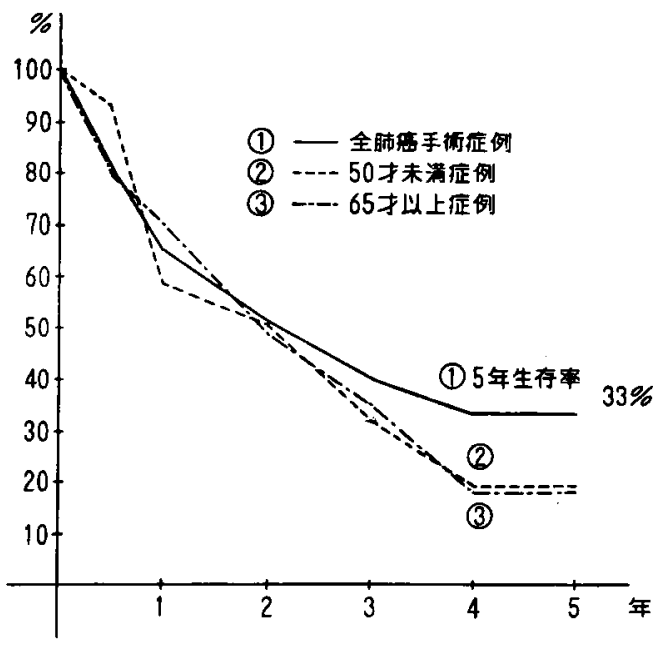

図 2 病期分類と予後（術後実測生存率）

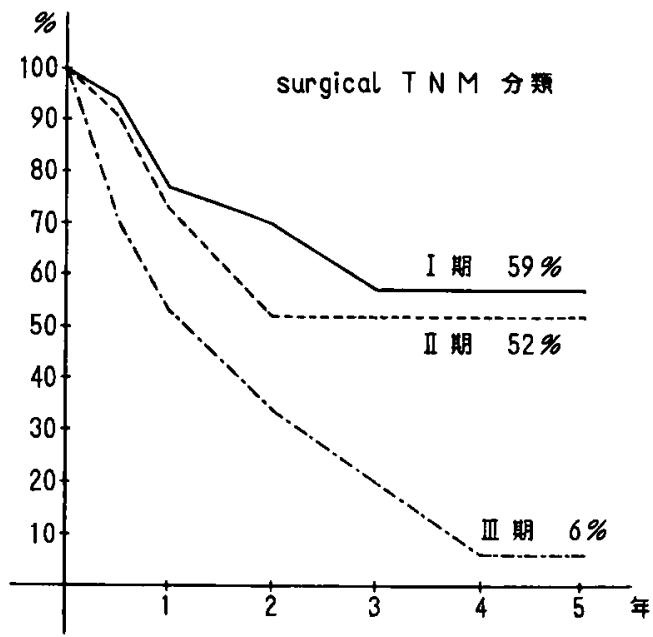

满で，その理由は若年者では病期が高く，65歳以上の高 龄者では早期合併死が比較的多いためと考えられる。

\section{5）病期分類と予後}

UICC, TNM 分類 (以下 surgical TNM 分類) k, 於ける病期分類での 5 年術後実測生存率は, 図 2 の如く で，I 期59\%，II 期52\%，III期 6\%であった． III期に於 ける生存率の著るしい低下は，期の大部分に於いて肺 外リンパ節，即ち，緃隔リンパ節転移が陽性であること による．この事は，n-factor である綎隔リンパ節転移 $\left(\mathrm{n}_{2}\right)$ が，最も予後に大きく影翌していることを示しが縰 隔リンパ節転移は，反対側もしくは遠隔リンパ節転移 が，既に存在している゙といっても過言ではない:この 事より $n_{2}$ 症例には縰隔への放射線療法と全身抗癌療法 に期待する所が大きい. 


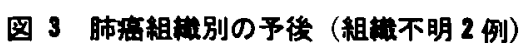

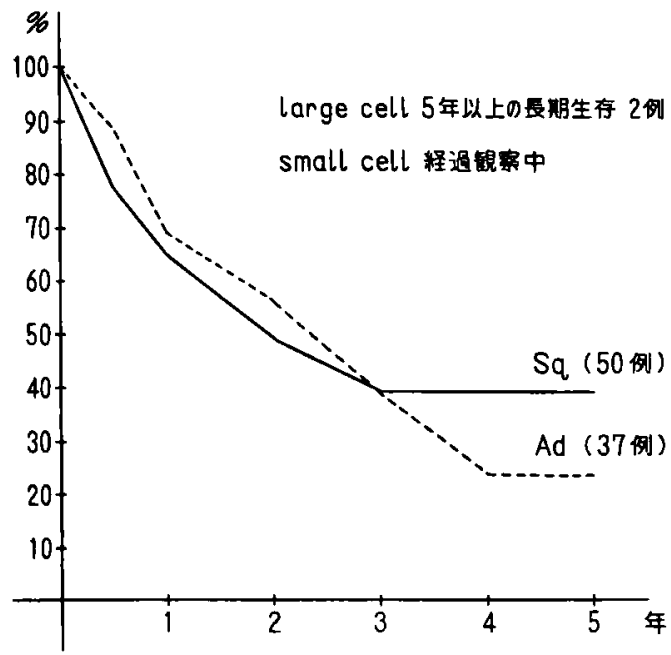

表 3 㢆㽝の最大径と轵隔 L.N. Meta. $\left(\mathbf{n}_{2}\right)$

\begin{tabular}{|c|c|c|c|c|c|}
\hline & & $0 \sim 2 \mathrm{~cm}$ & $2 \sim 5 \mathrm{~cm}$ & $5 \mathrm{~cm}$ 以上 & 計 \\
\hline \multirow{2}{*}{$\mathrm{Sq}$} & + & 0 例 & 3 例 & 15 例 & 18 例 \\
\hline & - & 2 & 12 & 15 & 29 \\
\hline \multirow{2}{*}{ Ad } & + & 1 & 8 & 9 & 18 \\
\hline & - & 4 & 13 & 1 & 18 \\
\hline \multirow{2}{*}{$\begin{array}{l}\text { large } \\
\text { cell }\end{array}$} & + & 0 & 1 & 1 & 2 \\
\hline & - & 0 & 2 & 1 & 3 \\
\hline \multirow{2}{*}{$\begin{array}{l}\text { small } \\
\text { cell }\end{array}$} & + & 0 & 0 & 2 & 2 \\
\hline & - & 0 & 0 & 1 & 1 \\
\hline \multicolumn{2}{|c|}{ 計 } & 7 & 39 & 45 & 91 \\
\hline
\end{tabular}

\section{6) 肺悹組別の予後}

图 3 の如く, 腺癌は 3 年迄は扁平上皮癌に比しやや良 好であるが，3 年を境に逆転しており，その理由の1つ として, 表 3 の如く腺澏は, 腫瘍の長径が $2 \sim 5 \mathrm{~cm}$ の うちから既に縦隔リンパ節転移を認める事が多く，この 早期リンパ節転移が予後を不良にしている原因と考えら れる. 大細胞末分化癌の場合は， 5 年以上の生存が 2 例 あり，ほぼ扁平上皮癌の予後と一致する，小細胞末分化 癌 3 例は，現在経過観察中であり，手術適応については 問題点を残している。

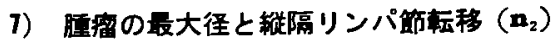

腺瘦は，比較的小型のうちから縦隔リンパ節転移をおこ しやすい（表 3)，一方扁平上皮泊は，最大径が $5 \mathrm{~cm}$ 以 上であっても縱隔リンパ節転移は約半数のみ陽性であっ
图 4 手術別実測生存车

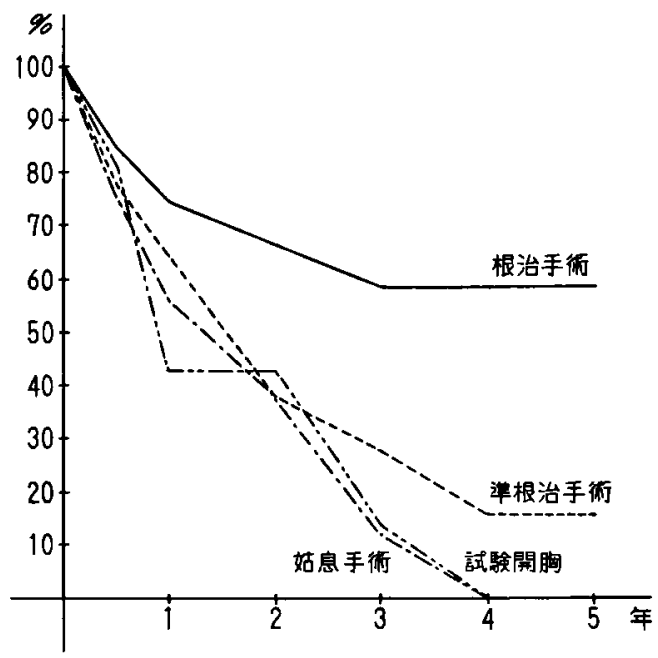

た. 腺癌に於ては， $2 \mathrm{~cm}$ 以下で既に縌隔リンパ節転移 があり，小型肺癌即ち早期肺癌とは言、難い22.

\section{8）手術別実測生存辛}

图 4 の如く，手術別 5 年実测生存率は，根治街 $59 \%$, 準根治術 $16 \%$ ，姑息手術及び試験開胸手術例では 5 年以 上の生存はない，しかし，試験開胸に於いても，2 年以 上経過し生存中の症例が 3 例あり，術後制癌療法を施行 している.

\section{II 肺瘱手術症例に対する問題点}

肺癌の手術に於ける現在の問題点は次のものがあげら れよう。

1) 椎隔リンパ篮轱移の予後

図 2 の如く， II 期症例の大部分は，n-factor によるも のであり，その他の T-factor 及び M-factor の影響は， 我々の症例では少ない：この縱隔リンパ節転移に対する 処置には，2つの異なった考えがあり，縦隔鏡にて綐隔 リンパ節転移陽性と診断されれば，手術適応外》とし， 手術療法よりも放射線及び化学療法等を行 5 施設があ る. 又，一方では徹底して，超抎大根治術を施行すると いった全く相反する施設もある゙，最近，転移のないり ンパ節は，免疫学的に肺癌の進展を防御しているといら 観点から，縱隔リンパ節の摘出は転移のあるリンパ節の みにとどめることが理論的に良いといった論文もあ る5. 現在我々は, 組織型によりその適応について考虑 している. 即ち, 扁平上皮癌に於いては, 徽底した郭清 に意義があると思われる6)，しかし縦隔リンパ流から言 えば縦隔リンパ節に転移が陽性であれば，既に反対側の 
表 4 高龄者肺症症例（70歳以上10例）

\begin{tabular}{|c|c|c|c|c|c|c|c|c|c|c|}
\hline 症例 & 年 & 性 & \multicolumn{2}{|l|}{ 手術 } & 組織 & 期 & 崳血 & TNM分類 & & 予後 \\
\hline A & 70 & 男 & 左下切 & 䓥 & $\mathrm{Sq}$ & III & 1400 & $\mathbf{T}_{1} \mathbf{n}_{\mathbf{2}} \mathbf{M}_{\mathbf{0}}$ & 死 & 1 年 7 力月 \\
\hline B & 76 & 男 & 右中切 & 根 & $\mathrm{Ad}$ & I & 400 & $T_{1} n_{0} M_{0}$ & 生 & 2 年11力月 \\
\hline $\mathrm{C}$ & 74 & 男 & 右中切 & 根 & $\mathrm{Sq}$ & 1 & 600 & $\mathrm{~T}_{1} \mathbf{n}_{1} \mathbf{M}_{0}$ & 死 & 85日目 \\
\hline D & 71 & 男 & 左下切 & 草 & $\mathrm{Sq}$ & II & 400 & $\mathbf{T}_{2} \mathrm{n}_{1} \mathbf{M}_{0}$ & 死 & 76日目 \\
\hline $\mathbf{E}$ & 75 & 男 & 右上中切 & 龺 & Ad & II & 400 & $T_{2} n_{1} M_{0}$ & 生 & 1年 4 力月 \\
\hline $\mathrm{F}$ & 71 & 男 & 右下如 & 根 & Ad & II & 1000 & $\mathrm{~T}_{2} \mathrm{n}_{1} \mathrm{M}_{0}$ & 生 & 1 年 4 カ月 \\
\hline G & 71 & 女 & 左上切 & 根 & $\mathrm{Sq}$ & I & 600 & $T_{2} n_{0} M_{0}$ & 生 & 1 年 1 力月 \\
\hline $\mathbf{H}$ & 70 & 男 & 右下切 & 㮛 & $\mathrm{Sq}$ & I & 400 & $\mathrm{~T}_{2} \mathrm{n}_{0} \mathrm{M}_{0}$ & 生 & 6 力月 \\
\hline I & 73 & 女 & 右上切 & 根 & Ad & III & 400 & $\mathrm{~T}_{2} \mathrm{n}_{1} \mathrm{M}_{0}$ & 生 & 7 カ月 \\
\hline $\mathrm{J}$ & 72 & 男 & 左下切 & 姑 & Ad & III & 400 & $\mathrm{~T}_{2} \mathrm{n}_{2} \mathrm{M}_{0}$ & 生 & 4 力月 \\
\hline
\end{tabular}

綎隔リンパ節への転移が充分考えられ，それに対して術 後放射線療法と全身抗癌剤投与を追加している.

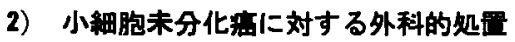

未分化癌12例の5ち, 小細胞末分化癌 5 例, 大細胞未 分化癌 5 例，分類不明のもの 2 例であるが, 肺癌の小細 胞末分化癌では同じ未分化癌としての大細胞末分化癌と の間には，その予後に於いて大きく相違している．大細 胞末分化癌の予後は，ほぼ扁平上皮癌の予後に一致して おり 5 年以上の生存が 2 例ある. 小細胞未分化癌では, 試験開胸に終った症例で，1年 6 ケ月の現在なお経過䂓 察中のものを除いては長期生存と呼べるものはない，小 細胞末分化癌 5 例の $5 ち 2$ 例に, SIADH (inappropriate secretion of anti-diuretic hormone) と癌性/イロパテ イーを呈したものがあり7，又分類不明の未分化癌 2 例 のうち1例に低ナトリゥム血症をともなっていた.

肺癌と紙巻きタバコの関連については扁平上皮癌に於 いては周知の如くであるが，末分化癌に於いてもBrin-

\section{表 5 術前合併症（70葴以上の高㱓者10例）}

\begin{tabular}{|c|c|}
\hline $\begin{array}{l}\text { 特記すべき合併症なし } \\
\text { 1. 呼吸器弈害 }\end{array}$ & 2 例 \\
\hline (1) 他の肺疾患既往 & 5 例 \\
\hline (2) 捈查によろ肺気腫所見 & 3 例 \\
\hline (3) 換気能低下 & 3 例 \\
\hline \multicolumn{2}{|l|}{ 2. 循環器障害 } \\
\hline (1) 高血王症 & 3 例 \\
\hline (2) 心奄図異常 & 2 例 \\
\hline 3. 所機能異常（既往も含む） & 3 例 \\
\hline 4. 機能異常 (PSP值低下) & 2 例 \\
\hline 5. 前立腺肥大症 & 1 列 \\
\hline 6. 糖 疗病 & 1 例 \\
\hline 7. dementia senilis & 1 例 \\
\hline
\end{tabular}

kman Index $の$ high risk group $^{8)}$ にあたる ものが, 12 例中10例あり，他の 2 例の5ち 1 例は25年間コールター ル作りに従事して括り，pneumokoniosis を指摘されてい た. 他の 1 例 5 年閒カキ打ち，5年間ブロック作りと いったかなり楾埃の多い場所に従事していた者であっ た，即ち肺癌と環境，職業; 契煙との関連は媣い.

手術適応については，小細胞未分化癌に対しては手衡 療法は予後に於いて放射線療法に優るものではなく，む しろ批判的な施設るあるが9，合併療法をバックに手術 をしている施設も多い，我々は，肺野型に於いては積植 的に切除を行ない合併療法を施行している.

\section{3）高令者肺䓌に対する手術}

当科に於ける70歳以上の高齢者手術例は10例である. 表 4 の如く，男性 8 例，女性 2 例でありいずれも肺葉切 除で，扁平上皮癌 5 例，腺癌 5 例である. 根治術 6 例, 準根治術 3 例，姑息手術 1 例である. TNM 分類ではI

\section{表 8 術後合併症（70歳以上高龄者10名）}

\begin{tabular}{|c|c|}
\hline \multicolumn{2}{|l|}{ 1. 消化器障害 } \\
\hline (1) 食欲不振 & 7 例 \\
\hline (2) 口内炎 & 2 例 \\
\hline (3) 肝機能障害 & 2 例 \\
\hline (C) 腹部起满 & 1 例 \\
\hline (5) 胃 痛 & 1 例 \\
\hline \multicolumn{2}{|l|}{ 2. 呼吸器媁害 } \\
\hline (1) 肺脚張不全 & 2 例 \\
\hline (2) 皮下気喱の增強 & 2 例 \\
\hline \multicolumn{2}{|l|}{ 3. 細環器㙔害 } \\
\hline (1) 心房細功 & 1 例 \\
\hline (2) 心室性期外収缩 & 1 洌 \\
\hline (3) 頉 脈 & 1 例 \\
\hline 4. 㭪後乏尿 & 1 例 \\
\hline 5. 胸痛が主訴 & 2 例 \\
\hline
\end{tabular}


表 770 歳以上肺癌手術症例の術前・後合併症

\begin{tabular}{|c|c|c|c|c|}
\hline 症例 & 年 & 性 & 術前合併症 & 術後合併症 \\
\hline A & 70 & 男 & $\begin{array}{l}\text { GOT } 61, \text { GPT } 52 \\
\text { PSP } 155^{\circ} \text { 値 } 15 \% \text { total } 60 \% \\
\text { 肺化掼症既往 }\end{array}$ & GOT 270, GPT 295 \\
\hline B & 76 & 男 & 肺結核，乾性助膜炎既往 & 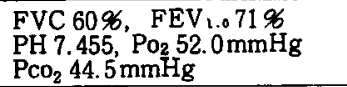 \\
\hline $\mathrm{C}$ & 74 & 男 & 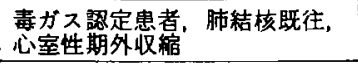 & 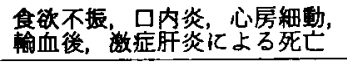 \\
\hline D & 71 & 男 & $\begin{array}{l}\text { 高血茞症, 完全右脚プロック, } \\
\text { 症 }\end{array}$ & $\begin{array}{l}\text { carcinostaticaによる免度不全 } \\
\text { 瞋下の pneumoniaによ死し }\end{array}$ \\
\hline E & 75 & 男 & 高血压症, 脳卒中既往 & $(-)$ \\
\hline $\mathrm{F}$ & 71 & 男 & $\begin{array}{l}\text { 高血正症, } \mathrm{DM} \text {, 総ビ } 1.2 \mathrm{mg} / \mathrm{dl} \\
\text { demantia senilis } \\
\text { PSP } 15^{\circ} \text { 値 } 20 \% \text { total } 47.5 \%\end{array}$ & $\begin{array}{l}\text { 総ビ } 8.7 \mathrm{mg} / \mathrm{dl} \text {, 直ビ } 7.5 \mathrm{mg} / \mathrm{dl} \\
\text { GOT } 204 \text {, GPT } 410, \text { ア } \\
30 \text { (toxic hepat it is'?) }\end{array}$ \\
\hline G & 71 & 女 & $(-)$ & 肺胿張不全 \\
\hline $\mathrm{H}$ & 70 & 男 & $\begin{array}{l}\text { 肺結核既往 (左上切後)，血清肝 } \\
\text { 炎既往 }\end{array}$ & $(-)$ \\
\hline I & 73 & 女 & $(-)$ & 不整脈，頻脈，之尿，肺膨張不全 \\
\hline $\mathrm{J}$ & 72 & 男 & 肺結核既往，毒ガス認定患者 & 食次不振, 腹部膨満感, 胸痛 \\
\hline
\end{tabular}

期 4 例，II 期 4 例，四期 2 例之比較的病期の低い者が多 い. 高齢者の予後は，高齢よりくる他病変の合併症の影 辢が強い10)，我々の症例では表 $\mathbf{5}$ の如く，他の肺疾患既 往 5 例，検查による肺気腫所見 3 例，換気能低下 3 例之 呼吸器系が多く，高血圧症 3 例，自覚症状のない心電図 異常 2 例, 肝機能異常 3 例, 腎機能異常等, 老龄化由来 の慢性疾患としての合併症が 8 例にみられた。術後合併 症では表 6 の如く, 消化器障害が多く; 呼吸器障害, 循 環器障害と続く、消化器障害では, 腹部等の手術と異な

\section{表 8 術前・中管理}

淮前（管理）
1. 呼吸管理
(1) 呼吸練習
(腹式呼吸，IPPB等）
(2) wet case $の$ 改善
（吸入療法，路度触解剂投与）
2. 抗生物䨘の術前投与
3. 既存合併症の把挃と予想される術後合併症 の対策

\begin{tabular}{l} 
術中（管理） \\
\hline 1. 麻 酉 \\
2. 手 術 \\
(1) 術式の逥択 (心肺機能と根治性) \\
(2) 出血と輸血
\end{tabular}

り早期より食䬣摄取が可能であるにもかかからず，術後 食欲不振を訴える者が多い.しかし4〜5日が経るにつ れて, 急速にその症状は消失する. 呼吸器障害の肺膨脹 不全や皮下気腫の増强は, 肺の老龄化むしくは病的な弾 力性の減弱, 肺葉切除や肺全摘後の死腔の縮少のための 肋骨切除, 横隔膜神経切除による横隔膜運動及び胸式呼

\section{表 9 術後管理}

1. 呼吸 (管理)

I. 呼吸器管理

(1) 体位変換

(2) 酸秦テント

(3) 略痰排出

(4) 補助呼吸

(5) 喀痰畩引 (ソ゚ンデファイバースコープ)

(6) 気管切開

II. 胸整ドレーン

2. 话瑟器 (管理)
(1) 脈・血王
(2) 渝液と輸血
(3) 菓解質 balance
(4) 血液ガス

3. 消化器 (管理)
(1) 水分と栄意
(2) 胃管㨉入 (早期抜去)

4. 感染防止

抗生物䨘の投与

5. 免度能のモ二タリング 
吸の減退，ならびに術後痛のための深呼吸不充分等が 原因となろう，语渨器障害は 3 例にみられたが，特に肺 癌の手術では，正常な血管床やガス交換の行なわれてい る肺胞自体を切除するわけであるから，既に予珰力の少 ない老㱓者にとっては相当の負担になると思われる，

表 7 に示すのは, 各症例に於ける術前後の合併症の比 較である. 症例Aでは，GOT 61，GPT 52 で慢性の肝 障害が考えられるが, 術後 GOT 270, GPT 295 と上昇 した. 症例 B では，肺結核及び 乾性肋膜炎の 既往があ り，術後 3 週目の動脈血ガス分析でも， $\mathrm{Po}_{2} 52.0 \mathrm{mmHg}$, $\mathrm{PCO}_{2} 44.5 \mathrm{mmHg}$ であり，低酸素状態と考えられる．症 例Cでは，心室性期外収縮を呈していたものに心房細動 が加わった例である，症例 Dでは，抗癌倣及びステロイ ド使用のための免疫不全状热と考えられる肺炎症例であ る. 症例 F では，術前総ビリルビン值が $1.2 \mathrm{mg} / \mathrm{dl}$ であ ったが, 術後総ビリルビン值が $8.7 \mathrm{mg} / \mathrm{dl}$, 直接ビリルビ ンが7.5mg/dl, GOT 204, GPT 410, アルカリフォスフ アターゼ30と閉塞性黄疸を思わせる Toxic hepatitis の 像を呈した，症例 I は, 肺の膨脹不全が一因をなした不 整脈，頻脈であると思われる。

我々の症例では，術後いずれも予想していたよりも， 喀药喀出の困難はなかったが，一般に高龄者に於いては 術前後の合併症の率は滈く，手術適応と禁忌に対し枚密 に検討されればならない11．症例 A及び症例 F の如き術 前の轱度の異常值に対しても細心の注意と合併症予防処 置をはらう必要がある。

表 8 及び表 9 は，肺癌手術の際の術前術後の我々が現 在用いている対策である. ます術前管理の第一は, やは り呼吸管理であろう。我々は，呼吸練習を充分過ぎる程
表 10 Mayo Clinic に於ける肺機能面での 手術限界（1977年）

\begin{tabular}{l|l}
\hline $\mathrm{FVC}$ & $50 \%(79 \%)$ \\
\hline $\mathrm{FEV}_{\mathrm{L} .0}$ & $50 \%(49 \%)$ \\
\hline $\mathrm{PaO}_{2}$ & $50 \mathrm{mmHg}(51 \mathrm{mmHg})$ \\
\hline $\mathrm{PaCO}_{2}$ & $50 \mathrm{mmHg}(43 \mathrm{mmHg})$ \\
\hline $\mathrm{DL}_{\mathrm{co}}$ & $50 \%(44 \%)$ \\
\hline $\mathrm{MMF}$ & $0.51 /$ 积 \\
\hline 肺動眼王 & $50 \mathrm{mmHg}$ \\
\hline
\end{tabular}

（）内は当科70瓷以上の症例の下限界

指導している. 又吸入療法，喀痰融解剤の投与による wet case の改善と，数日前より広域スペクトルの抗生 物質を投与し感染予防と潜在性の感染を抑制している. 既存合併症の把握と予想される術後合併症の対策は特に 重要である．術中では主として術式に対する耐術心肺機 能の考虑上根治性に対する術式の選択は充分検討されな ければならない，術後管理に於いても重要であるが，正 常血管床及びガス交換をあずかる肺害啠を大きく切除す る肺癌症例では，それだけ失血に対する個体予備能力が 低下する事を常に念頭に直かねばならない. 問題は癌が， 肺機能面（換気機能及び肺拡張能力14) に於いてどこま で占执しているかであり，我々は181I-MAAを用いた肺 血流比測定や肺動脈造影を参考にしているが，当然のこ とながら，既にガス交换の行なわれていない部分が，切 除の大半であれば，比較的肺機能面での予後は良い，一 方早期の比較的小さな癌では，それだけ切除されるべき 肺葉自体の機能が，失われていないわけであるから，肺

表 11 早期死亡の12例（90日末満）

\begin{tabular}{|c|c|c|c|c|c|c|c|c|}
\hline 症例 & 年龄 & 些 & 手 & 林 & 組諎 & 死 & 手述日より & 期 \\
\hline A & 66葴 & 男 & 右上切 & 根 诒 & $\begin{array}{l}\text { large } \\
\text { celf }\end{array}$ & 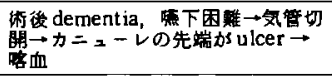 & 37日目 & 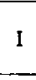 \\
\hline B & 63胔 & 男 & 右中下切 & 根 诒 & Sq & 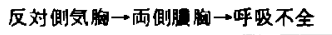 & 40 日目 & I \\
\hline c & 68 缄 & 男 & 左 全 摘 & 草根治 & $\mathrm{Sq}$ & bronchoblennorrhoea $\rightarrow$ pneumonia & 46日目 & III \\
\hline $\mathrm{D}$ & 66葴 & 男 & 右全摘 & 堂根站 & $\mathrm{Sq}$ & 实然 sputumで窒急?（気胸？） & 56日目 & III \\
\hline $\mathrm{E}$ & 64 裁 & 男 & 右上切 & 莗根治 & $\mathrm{Sq}$ & 教症肝炎（四血㖟） & 57日目 & III \\
\hline $\mathrm{F}$ & 64 葴 & 男 & \multicolumn{2}{|c|}{ 試殹開胸 } & $\mathrm{Sq}$ & 放射線治療中实然喀血 & 58 日目 & 四 \\
\hline G & 63歳 & 男 & 左 全 摘 & 姑 息 & $\mathrm{Sq}$ & 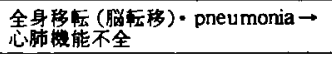 & 60 日目 & 目 \\
\hline $\mathrm{H}$ & 50 咸 & 男 & 左全扬 & 姑 息 & Ad & 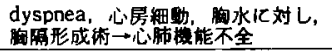 & 63日目 & III \\
\hline I & 71䖒 & 男 & 左下切 & 辢㮛炲 & $\mathrm{Sq}$ & $\begin{array}{l}\text { pneumocyst is carinii ? 真菌㾦? } \\
\text { carcinostatica } ? \rightarrow \text { pneumonia }\end{array}$ & 76 日目 & II \\
\hline $\mathbf{J}$ & 51 瓷 & 男 & 左 全 掊 & 姑 息 & Ad & $\begin{array}{l}\text { postope bleeding } \rightarrow \text { DIC, pneu- } \\
\text { monia, empyema }\end{array}$ & 76日目 & III \\
\hline K & 63戴 & 男 & 左上切 & 根 治 & Sq & 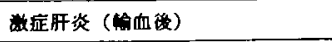 & 83日目 & II \\
\hline $\mathrm{L}$ & 74咸 & 男 & 右中切 & 根 枲 & $\mathrm{Sq}$ & 数症訮炎（㢵血後） & 85日目 & I \\
\hline
\end{tabular}


機能面での予後は広籍围切除に於いては特に注意せねば ならない，予供能力の低下といら事を考えれば，術式の 嘾択は術後の経過に大きく影謷する。

表10は，Mayo Clinicに於ける肺機能面での手術限界 であるが，50 といら数字が基䒜となっている（）内 は，70歳以上の当科莚例の下限值を示したものである が、下隄值が重複している症例はなかった。

次に街後管理では, wet case 以外では $2 \sim 3$ 日目が 最も喀出する筑の量が多く，開胸術後は約 3 週目まで $\mathrm{Po}_{2}$ の低下があり13)，常に患者は，低酸素状態にある ので頻回の喀吹引，必要があれ吃気管切開による気道 の磼保, 人工呼吸器による補助換気を, 適宜迅速に施行 すべきである. 郝後の無気肺には，特に注意し直ちに対 処せかばならない，又術後の皮下気厙は少なからず胸腔 ドレーンが原因の事もあり，気管支瘦や肺掼を疑 5 前 に, 胸腔ドレーンが確実に効いているかどうか充分碓か めなければならない，又我々の症例の様に，消化器障害 の事も高いために水分及び栄養のバランスにも注意を払 わねばならない，胃管が挿入されている場合は，郝中迷 走神経損傷等による急性胃搪張以外は出来るたけけ早期に 抜去し肺合併症を予防すべきだと思われる。抗澏凨やス テロイド等の免疫抑制作用のある薬刜使用により，免疫 能の低下によると考えられる肺资により死亡した例もあ り，細胞性免疫能のチェック（免疫能モニタリング）は 充分検討されるべきであり，又免疫能モニタリングは再 発及び転移等のチェックとしても有効であると思われ る.

\section{4) 早期死亡例の検討}

術後 1 ケ月以内の手術死亡例はまだ経験していない. 90 日末満の早期死亡は，12例である（表11）。平均年跲 は64歳で，いずれも男性であった，根治術が 4 例，準根 治術 4 例，姑息手術 3 例，試験開胸術 1 例であった。 こ のちち全摘術は 12 例中 5 例を占めた. 組織別では, 扁平 上皮癌が 9 例，腺癌 2 例，大細胞未分化癌 1 例であっ た. 病期分類では，I 期 3 例， I 期 2 例，III期 7 例であ た.

早期死亡の原因には，(1)手術適応の判定過誤(2)手術操

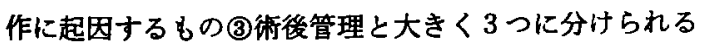
が11)，それぞれが独立したものではなく，それらが組み 合わさり悪循環に宿る場合が多い，例えば，症例 A よ らに街後痴呆に始まり，誤领を起こし，低酸素状態改善 の目的の気管切開が不幸な転㷌をとった例もあり，充 分な注意を要する. 症例 B では, 反対側気胸が衔後 2
日目に起り，最終的には两側澧胸を起こし，呼吸不全 にて死亡しているが，肺熟胞が対側肺にあったのか， それとも縋隔に損傷があったのかは剖検していないので 不明である. 症例 Cの場合 $\mathrm{T}_{2} \mathrm{n}_{2} \mathrm{M}_{0}$ で四期であったが， 全摘術を行い経過良好で制癌郕を投与し，胸水の眝留が あるにも拘らず胸剠形成を行なわず，後庴法のため， 他科入転科後笑然気管支瘦が生し健側肺への胸水の吸引 により肺炎を起こし死亡した，症例Dでは，ある日何ら 誘因なく突然死亡し, 剖検の時胸腔内が異常陽仕であっ たが，解剖所見では特に気管支嫶，肺度その他の異常所 見は得られなかった。この患者は全摘症例で症例C と同 様注全摘術後の患者に対しては，予備力の極度の低下 を考虑し，細心の注意を常に念頭に置かねばならない。 症例 $\mathrm{E}$ は症例 $\mathrm{K}$, 症例 $\mathrm{L}$ と同様に輸血後の激症肝炎で死 亡したが，術中輸血量は，症例 $\mathrm{E} 2000 \mathrm{ml}$ ，症例 $\mathrm{K} 600 \mathrm{ml}$ ， 症例 $\mathrm{L} 600 \mathrm{ml}$ で肺機能も病期も比較的良く長期生存が 期待出来たものばかりであった，症例 $\mathrm{F}$ は， $\mathrm{T}_{3} \mathrm{n}_{2} \mathrm{M}_{0}$ で 四期であったが，試験開胸に終った後，放射線治療中次 第に中心境死様の空洞が 出現し，その後突然喀血死し た. 術前肺動脈造影にて基部の㹟窄が認められ，この可 能性充分予見出来たものと考えられる. 症例 $\mathrm{G}$, 症例 Hは共に心肺機能不全により死亡しているが，典型的な のは症例Hで ${ }^{131}$ IMAA による肺血流比がほほ同率を示 した症例に全摘を行ったもので, 術中肺結核 (昭和19年 肺結核の既往があったが) のための府着により出血が多 く, 輸血が3000 $\mathrm{ml}$ に及んだ应例で, 術後上り呼吸困難 が強く心房細動を呈し, 胸水眝留に対する胸郭成形施行

因 5 全摘術後の実測生存率 (16 例)

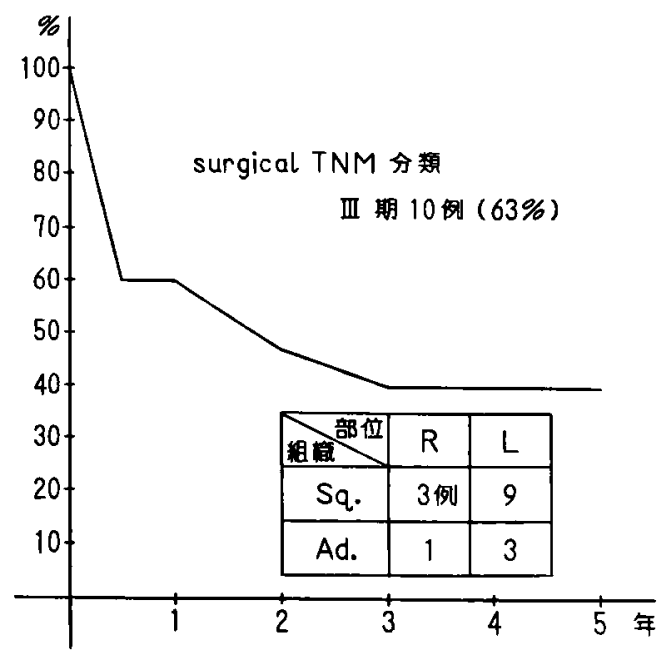


後，FVC $30 \%$ となり呼吸不全で死亡した．手術法に問 題を残した症例であった，症例 I では， $\mathrm{T}_{2} \mathrm{n}_{1} \mathrm{M}_{0}$ に準根 治術を施行したが，抗澏剂 7 回目投与頃より口内炎の出 現あり，直ちに抗癌凨を中止しそれに対する治療を始め たが治療開始後 2 週目頃より突然発熱，白血球及び血小 板の诚少をきたし，胸部レ線にて全肺野にビマン性粒状 䧔影が日タ增大し呼吸困難が強く死亡した。 ステロイド 使用及び抗癌剤使用のための免疫不全状热下に於ける pneumocystis carinii, 真菌症, 又怯 MMC に上る間啠 性肺次が原因として考えられるが，剖検を施行していな い. 症例 Jでは全輸血量が8600ml となり，大量輸血， 出血傾向といった德循環を絽り返し不幸な転帰をとっ た.

我々の症例では90日末満の早期死亡例12例の5ち5 例 が全摘例で，いずれも全摘ゆえの予備力低下による死亡 で, 根治性を高めるために切除範囲を应大するといら事

表 12 合併宊法（広大 2 外）

1. 術前

気管支動脈内制癌剂注入

2. 術中

MMC CQ BLM etc

制癌戍全身投与

$\mathrm{MMC}$

3. 衙後

\begin{tabular}{|c|c|c|c|}
\hline 手術時病䉾准展 & 切除 & 放射線 & 华学 \\
\hline 肺内限局リンバ節転移 (一) & 0 & & 0 \\
\hline 気管支肺リンパ節 (肺内) 転移 $(+)$ & 0 & & 0 \\
\hline 肺門，絬隔リンパ的枟移 $(+)$ & O & $\mathrm{O}$ & 0 \\
\hline 肺門，綎隔浸閏 & $?$ & 0 & 0 \\
\hline 肋膜，胸壁漫潤 & $?$ & 0 & 0 \\
\hline
\end{tabular}

注？：肺切除は症例によって決める

表 13 長期生存例（5 年以上10例）

\begin{tabular}{|c|c|c|c|c|c|c|c|}
\hline 症例 & 年齢 & 性 & \multicolumn{2}{|c|}{ 手術 } & 租 & 予 後 & 期 \\
\hline A & 62歳 & 男 & 右上切 & 根 治 & $\mathrm{Sq}$ & 11年 7 カ月 & I \\
\hline B & 58歳 & 女 & 左上切 & 根 治 & Ad & 8 年 4 力月 & I \\
\hline C & 64葴 & 男 & 左上切 & 根 台 & Sq & 7 年10カ月 & I \\
\hline D & 57歲 & 女 & 右上切 & 根 治 & $\mathrm{Sq}$ & 7 年 & I \\
\hline $\mathrm{E}$ & 62歳 & 男 & 右 全 摘 & 準根治 & Ad & $\begin{array}{c}6 \text { 年 } 5 \text { 力月 } \\
\text { (死亡) }\end{array}$ & II \\
\hline $\mathrm{F}$ & 59歳 & 男 & 右中下切 & 根 治 & Sq & 6 年 4 力月 & I \\
\hline G & 49歳 & 男 & 右下切 & 準根炲 & large cell & 6 年 2 力月 & III \\
\hline $\mathrm{H}$ & 57歳 & 男 & 右上切 & 根 治 & large cell & 5 年 & I \\
\hline I & 57瓷 & 男 & 左 全 摘 & 根 治 & $\mathrm{Sq}$ & 5 年 & II \\
\hline $\mathrm{J}$ & 60歳 & 男 & 左上切 & 根 治 & $\mathrm{Sq}$ & 5 年 & I \\
\hline
\end{tabular}

には他病死との兼合いに於いて問題を残している，特に 肺全揞という掂大根治街的考えは，必ずしも肺满の根治 性に連がるとは思われず，気管支形成術等の肺機能温存 手術的考之16や，肺癌合併撚法の工夫が望まれる様儿思 われる. しかしながら图 5 の如く我々の全摘例16例での 5 年実測生存率俚，血期が10例を占めるにもかかわらず $40 \%$ となっており，症例が少ないが，根治性を高めるた めの手術適応及び手術法を検郡し, 術後管理を厳重に行 えば，かなりの予後も期待できる.

\section{5) 合阱嵰法}

合併療法は原則として表12の如く行っているが， MMC を中心とする制癌㓮の気管支動脈内注入(SBAI) ${ }^{152}$ 術後の化学療法として FMC, FAM を施行しており，扁 平上皮癌に対しては BLM を肺機能に注意しながら併 用している，図1が示しているように，肺癌に於いては $2 \sim 3$ 年の閒に急激に生存率が低下しそれ以後生存して いる症例は長期生存も期待できる。.よってその期閒迄 は，少なくとも確立した follow up が必要であり，山 ロ18)はその閒の LTIC (long time intermitend chemotherapy）の必要性を述べている，又，現在合併療法と しての免疫療法を積極的に取り入れている施設もあり， 又, その効果についての論文も多い17218319．我々はそれ については, 免疫能のチェックと共に免疫療法について 現在検郡中である.

\section{6) 長期生存例}

5 年以上の長期生存例は 10 例あり (表13)，平均年龄は 59歳で，男性 8 例，女性 2 例，そのうち2例全摘であ

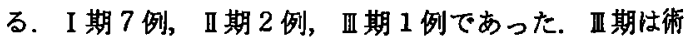
後病理組織検査で気管支断端に癌細胞陽性であった例で あるが, 断端再発の徴候むなく，術後 6 年 2 ケ月目の現 在もなお生存中である.

\section{おわりに}

肺癌の外科的治療成績は他搭器癌に比して悪い，し加 し早期部断, 合併療法の進歩により長期生存例は増加し ている，手街適応，手術法を厳しく設定し，細心の管理 の下に手術療法を施行すれば，街後成績の向上は大いに 期待できるものと考えている. 我々は現在問題点とされ ている III期 $\mathrm{n}_{2}$ 症例に対する治療法，小細胞未分化癌に 対する手術適応，高龄者肺癌と全摘術等の䚁点から考察 を綂け，今後の成續向上に努めたい．

本論文の要旨は，昭和52年10月第39回日本烸床外科医 学会総会, 11 月第68回広島胸部疾患学会, 12月第52回中 国四国外科学会に於いて報告した。 


\section{责文献}

1) 井上権治, 麻野博智, 吉本 忠他: 肺癌手術根 治性に咸する検討，胸部外科，22：892,1969.

2）富田正雄, 柴田絠一郎, 迲 泰邦他: 小型肺癌 と早期肺癌の関連珄についての臨床的考察, 外 科, $39: 747,1977$.

3) Reynders, H.: Mediastinoscopy in bronchogenic carcinoma. Dis. Chest, 45: 606, 1964.

4) Salzer, G.: Die Chirurgie der malignen Lungengeschwulst. Chirurg., 41 : 289, 1970.

5) 大田満夫, 飯田 彰, 植田英彦他 : 進行肺癌の 治㙩とその免疫学的考察, 胸部外科, $30: 581$, 1977.

6) 成毛韶夫, 米山武志, 尾形利郎他 : 絎隔りンハ 節転移のある肺癌に対する外科治療, 胸部外科, $30: 459,1977$.

7) 蔵田裕彦, 藤井俊宏, 児玉求他: Neuro-myopathy と低ナトリウム血症を呈した小細胞癌の 1 例, 外科, $40: 409,1978$.

8) 西村 梳，杉浦孝彦：早期肺癌の診断一集団検 診によるアプローチ一，臨床外科， $32: 1213$ ， 1977.

9）加藤敏郎，小池脩夫，戸部龍夫他：未分化小細 胞癌の放射線治療, 肺癌, $13: 1,1973$.
10）原 信之, 吉田猛朗, 大田満夫他 : 高令者の術 後合併症一肺瘦症例を中心にして一, 日本胸部 臨床, $31: 984,1972$.

11) 児玉 求: 肺癌の外科的治療, 広島医学, 26: 451,1973 .

12）平本雄彦, 西田修実, 西本幸男他: 原発性肺癌 の肺機能, 日本胸部臨床, $36: 834,1977$.

13）田中弘一：遷延性術後低酸素血症に閔する臨床 的研究, 日胸外会誌, $23: 945,1975$.

14）石原恒夫：気管支・気管成形術の適応と手技, 臨床外科, $32: 1247,1977$.

15）西龟正之, 藤井俊宏, 児玉 求他 : 肺癌に扣け る選択的気管支動脈造影, 広島医学, $31: 24$, 1978.

16) 山口 豊 : 肺癌の非治革切除後の長期生存の要 因分析，日本胸部臨床，36:239,1977.

17) Holmes, E.C.: Immunology and lung cancer. The atlas of thoracic surgery, 21:250, 1976.

18）安元公正, 真鍋英夫, 山村雄一他 : 肺癌, 外科 診療, $19: 1420,1977$.

19) Stewert, T.H.M., Harris, J.E., Crook, A.F., et al.: Specific active immunochemotherapy in lung cancer: A survival study, The Canadian Journal of Surgery, 20: 370, 1977. 